\title{
Determinants of Micro-Insurance Ownership Decision: Empirical Evidence from Informal Commercial Market Business Operators in Ghana
}

\author{
Augustine Kwadwo Yeboah \\ Ghana Baptist University College, PMB, Kumasi-Ghana \\ yeboagus@yahoo.com
}

\begin{abstract}
This study empirically examines determinants of Micro-insurance ownership decision in Ghana. Probit estimation technique was used to examine data sourced from 612 informal commercial business operators in selected urban market centers in Ghana. The results reveal that financial literacy has significant effect on micro-insurance ownership decision among informal commercial market business operators in Ghana. The study also found income, access to credit, trust, market levy, Marital status and household headship status as other major predictors of micro-insurance ownership decision. Premised on these, the study recommends financial literacy education intervention by micro-insurance providers to increase microinsurance patronage. Micro-insurance providers should invest in building reputation to encourage participation in micro-insurance scheme. Also, efforts of government should focus on improving access to credit facilities and income generation prospects among informal businesses operators in Ghana.
\end{abstract}

Keywords: Risk; Micro-insurance; Commercial Business Operators; Probit; Ghana

\section{Introduction}

Risk and its negative impact on productive asset, livelihoods and income has become issue of major concern in recent times. For the majority of informal business operators in developing countries, uninsured risk exposure to livelihoods remains a serious driver of poverty(Fafchamps, 2010). This assertion makes it imperative to find coping mechanism to help mitigate the adverse impacts of risk occurrences. In particular, micro-insurance has been identified as important risk mitigating mechanism for poor households who are mainly engaged in informal sector activities. The close link between vulnerability to risk occurrences and material poverty has been well emphasized (Crayen, Hainz, \& Stoh de Martinez, 2013). Though, microinsurance has been identified to offer solution to negative impact of risk and welfare enhancement through sustainable income and consumption smoothing(Akotey \& Adjasi, 2014); decision to insure is constrained among other factors by poor financial decision making due to financial illiteracy and inadequate financial resource among small business owners (Ito \& Kono, 2010; Akotey, Osei, \& Gemegah, 2011). Despite this knowledge, empirical researches explaining decision to own micro-insurance have remained rare, particularly in Ghana. Concerns have been raised that in developing countries less than one-half of the population have access to formal financial market due to financial exclusion (Arun \& Bendig, 2010). Further studies estimate that more than 400 million poor and low-income people are not being served by any microfinance program (IFAD, 2004; Annim \& Alnaa, 2013). Therefore, responding to impacts of risk through micro-insurance remains essential concern to the poor and the vulnerable, particularly in poor developing economies.

Though, the literature indicates that micro-insurance is important tool for risk management, social protection and fight against poverty (Janzen \& Carter, 2013; Kishor, 2013; Mukhtar, 2013; Akter, 2012; Parvathi, 2012; Hoefer \& Midgley, 2012); evidence shows, generally low patronage of micro-insurance, particularly in Ghana (National Insurance Commission, 2010). Concerns raised in recent times about patronage of micro-insurance point to lack of knowledge as a major cause of low patronage of financial products, particularly microinsurance; a situation common in developing countries (World Bank, 2009; Cole, Sampson, \& Zia, 2009). Other studies claim that individuals and households with limited knowledge of the features of contemporary financial services tend to have poor financial planning and subsequently poor financial decision making(Stango \& Zinman, 2006; Lusardi \& Mitchell, 2007). This presupposes that increasing consumer financial knowledge through financial education has the potential of improving welfare through effective financial decision making. In recognition of the importance of microfinance service, particularly microinsurance as favorable financial buffer in times of unexpected needs; it is on record that majority of the population are without any form of such financial cushioning (Ackah \& Adobea, 2012). This situation is, partly attributed to uncontrollable socio-economic factors(Fofie, 2016);an indication of weak system of offering 
social protection to the poor and the vulnerable. Despite these compelling revelations, researchers passively discuss micro-insurance and do not consider possible determinants of decision to insure. This study therefore sought to investigate empirically, major predictors of micro-insurance purchase decision in Ghana.

\section{Literature Review}

As a facet of the microfinance industry, micro-insurance is hailed as a new developing paradigm in microfinance for risk management and poverty reduction for the poor and financially excluded (Holzmann, Sherbune \& Tesliuc, 2003; Adjei, Arun, \& Hossain, 2009). It is argued that to fill the deficit gap of public social security scheme and expand economic opportunities to the poor and the vulnerable, micro-insurance plays a significant role(Tabea, 2010; Fletschner \& Kenney, 2011).Theoretically, sinking into poverty cannot simply be equated to lack of income but timely intervention of income at the time it is most needed(Bateman, 2010). Thus, some early economists have earlier emphasized the need to ensure material progress through removal of financial market imperfections, which impede material progress and prosperity(Gurley \& Shaw, 1967; Mckinnon \& Goldsmith, 1973). This indeed presupposes that the harsh and difficult economic circumstances of the poor form solid foundation to impede smooth process to arrest perpetual poverty emanating from uninsured risk (Guha-Khasnobis \& Ahuja, 2004).To emphasize the need to ensure removal of financial market imperfections Hassan, Sanchez and Yu (2011) attribute lack of financial market participation to inherent information asymmetry and suggest strong connection between effective financial intermediation and removal of information asymmetry. Thus, building on this theoretical exposition, Dulleck and Kersschbamer (2006) argue that efficient market performance should be contingent on overcoming information asymmetry through a mechanism that empowers consumers to build on accurate picture of what they have to buy.

Empirical Literature Review: Empirically, literature on factors influencing decision to own micro-insurance scheme points to various economic, institutional, social and demographic factors. This section, therefore, review empirical literature on determinants of micro-insurance ownership decision. A study in Bangladesh by Chowdhury, Rahman and Afza (2007) the authors examined perceptions towards insurance scheme in a survey involving 416 respondents. Employing descriptive analysis, the study revealed that one important predictor of insurance purchase decision was trust. The study concluded that effective patronage of insurance hinged on the ability of firms in the insurance industry to invest in building reputations by improving upon their service quality gaps. Though, the conclusion of this study sounds appealing, the role of financial literacy as a key variable among the determinants of micro-insurance patronage was not emphasized. In agreement to the assertion by Chowdbury, Rahman, \& Afza(2007), Yusuf, Gbadamosi and Hamadu (2009)using a survey data drawn from 392 respondents in Nigeria. The study revealed that public perception has strong link with micro-insurance patronage. This assertion suggests that to ensure effective marketing of insurance service, micro-insurance service providers must begin the walk from reliable contract agreement to boost confidence among existing and potential micro-insurance market participants. In spite of this, the study failed to include in its analysis a key driver of insurance marketing and availability of information and financial knowledge of the potential insurer. We build on this by empirically investigating the effect of financial literacy on microinsurance ownership decision in Ghana.

Gautam and Kumar (2012)studied into attitudes of Indian consumers towards insurance services with a survey data from 377 respondents. The results from the Analysis of Variance (ANOVA) showed that sociodemographic and economic factors namely, age, gender, marital status, level of education and household monthly income have significant impact on consumers' attitudes towards purchase of insurance services. The study further found consumer awareness about insurance as one major predictor of insurance participation. One conclusion is that awareness creation about importance of pooling risk through insurance is vital for successful insurance service provision. In their investigation into micro-health insurance policy renewal, Boateng and Awunor-Vitor (2013) confirm awareness and/or knowledge as a potential channel of patronage of micro-insurance in an empirical study in Ghana using logistic regression model to analyze data sourced from 300 households. The study revealed that poor service quality, inadequate financial resources, financial education, marital status and gender significantly influence reasons to enroll and remain in insurance. The study further indicates that community education and sensitization programs can prove effective in ensuring optimal access to the insuring public. The conclusion of the study provokes further empirical investigation, 
particularly at the micro level, to test the claim of the link between knowledge and micro-insurance ownership decision.

In a related study, Gaurav, Cole and Tobacman (2011) conducted field experiment into rainfall microinsurance among 600 informal small-scale farmers in India. Using randomized controlled trial, the authors tried to evaluate the effect of financial literacy training on insurance take-up. It was empirically revealed that financial education had a positive and statistically robust effect on micro-insurance adoption. After controlling for the regressors, the authors concluded on a strong conviction that, notwithstanding the complexity and novelty of micro-insurance product to the poor and the vulnerable, educational intervention programs directed towards financial literacy had high likelihood of making people adopt micro-insurance scheme as financial risk coping tool. Though the revelation about possible effect of financial literacy on microinsurance take-up was impressive, it was not clear if the problem of potential endogeneity emanating from reverse causality between financial literacy and micro-insurance take-up decision was resolved. This creates inconsistent estimates thus, making the claims of the study inconsistent and inconclusive. Negi and Singh (2012)conducted a study into demographic factors affecting purchase of micro-insurance in India. Using exploratory study, data was drawn on 613 respondents; with the sample consisting of policy holders of both private and public life insurance companies operating in Uttarakhand. The mean difference analysis using Analysis of Variance (ANOVA) test revealed that the mean among different gender categories of respondents showed that male customers are more sensitive to product quality whereas their female counterparts give more preference to customer friendliness. The study concludes that in dealing with customers, insurance service providers should be gender sensitive in dealing with potential clientele in their insurance service delivery. Though, the orientation of the study was clear, the effect of other equally important demographic characteristics of the respondent such as number of dependents and sex have not been emphasized.

Veron and Majumdar (2011) tried to build on the micro-insurance ownership decision model in their quest to examine micro-insurance distribution in India. Using the Corporate-NGO Partnership Model (CPM) and employing descriptive analysis, the authors found that delivering micro-insurance had high cost implications for both formal insurance companies and NGOs. The study again demonstrated that understanding of microinsurance services was a major concern; as potential micro-insurance client had limited comprehension of insurance matters and the concept of making financial commitment for something that was unlikely to yield any return. Though the revelation from the study sounds appealing, failure to clearly address the issue about financial literacy education as a conduit for financial knowledge has implication for conclusions drawn from the study. Akotey, Osei, \& Gemegah(2011)examined factors influencing demand for micro-insurance services using cross-sectional data sourced from 100 informal sector workers. Controlling for other regressors, the probit regression model revealed that insurance knowledge was a significant determinant of micro-insurance demand. The study concludes that ensuring financial education intervention to improve literacy of what micro-insurance contract entails is a major conduit for effective micro-insurance delivery. However, one downside of the study is a potential endogeneity embedded in possible reverse-causality between ownership of insurance and insurance knowledge. Again, using limited sample size of only 100 respondents has implications for the generalization of the study.

\section{Methodology}

The study is cross-sectional in nature and employs a causal study design. The quest to utilize causal research design is generally motivated to maximize objectivity. The causal research design is also amenable to replicate and guarantees generalization of the research findings. The data was obtained from 612 informal commercial market traders in six selected urban commercial market centers in northern, central and coastal Ghana through in-person face-to-face interview. The survey data contains information on features such as the number of times that the respondent's business has been exposed to risk, micro-insurance ownership decision, number of years in business, Trust in micro-insurance, credit access, income, location of business, market levy, number of economic activities engaged in as at the time of this study, sex, marital status and number of dependents.

Target Population and Sampling: The study targeted the economically active informal commercial market business operators who conduct daily trading activities in the selected urban markets centers. The 
justification for the concentration on informal urban market business operators emanates from the fact that, this group who conduct daily commercial activities in these market centers is relatively more susceptible to hazards; because most of them have their business assets permanently situated in the markets. Moreover, this target group is easily accessible for purposes of information gathering. The extent to which the findings of the study can be generalized is important in every research. Thus, to ensure reliability in generalizing the findings of this study, the study population was first grouped into clusters across the three main ecological zones in Ghana. Thus, the study employed multi-stage cluster sampling technique. First the study was segmented into three main zones (clusters): northern cluster, central cluster and coastal cluster. Second, two (2) market centers were selected from each cluster based on number of vibrant markets centers in each cluster. The study selected only vibrant urban market centers where predominantly market participants had their business assets permanently situated. Based on this criterion, each cluster was identified with four (4) main major market centers. Then, two (2) most relatively vibrant markets were selected from each zone (cluster). The respondents were selected by convenience from the market centers.

Model Specification and Estimation Technique: To estimate the determinants of micro-insurance ownership decision, the dependent variable micro-insurance ownership denoted by $\boldsymbol{O} \boldsymbol{w} \boldsymbol{n}_{-} \boldsymbol{M I}$ is captured as a dichotomous dependent variable. In this manner, it is important to use a model with suitable and appropriate cumulative distribution function preferably, a probit model. A person's desire to own micro-insurance is not directly observed. If the observed binary outcome variable $(Y)$ is an expression of whether or not the person decides to own micro-insurance or not, then, for such a binary outcome, the underlying latent propensity or desire to own micro-insurance is given by $y^{*}$. Therefore, when a person's desire is greater than zero $\left(y^{*}>0\right)$ then a person has positive decision towards micro-insurance ownership. In this light, the definition of a binary response variable can be specified as follows:

$Y_{i}=\left\{\begin{array}{l}1 \text { If } y^{*}>0 \\ 0 \text { If } y^{*} \leq 0\end{array}\right.$

Given the latent variable model, we specify the probability of individual owning micro-insurance as given in the following specification:

$\operatorname{Pr}(y=1)=\operatorname{Pr}\left(x^{\prime} \beta+\varepsilon>0\right)$

$=F\left(x^{\prime} \beta\right)$

$$
=\operatorname{Pr}\left(-\varepsilon<x^{\prime} \beta\right)
$$

$F(\cdot)$ denotes the cumulative distribution function with frequency of- $-\varepsilon$.

Thus, we assume the existence of an underlying unobservable latent dichotomous outcome $\left(y^{*}\right)$ which defines the generalized form of the probit regression model as:

$y^{*}=\alpha+\boldsymbol{X}^{\prime} \beta+\varepsilon_{i}$

Where, $y^{*}$ is a dichotomous dependent variable, $\boldsymbol{X}$ is vector of explanatory variables, $\alpha$ and $\beta$ are parameters to be estimated and $\varepsilon_{i}$ is the error term. Therefore, the marginal effect of a change in a given influencing variable on the outcome variable expressed as; $\left(\partial y / x_{i}\right)$ becomes $F\left(x^{\prime} \beta\right) \beta_{i}$.

The probit model is therefore specify as follows:

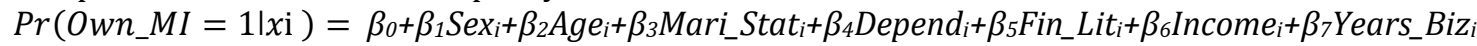
$+\beta_{8}$ MarketLevy $_{i}+\beta_{9}$ Credit_access $_{i}+\beta_{10}$ Trust $_{i}+\beta_{11} H h H_{i}+\beta_{12}$ Numbacty $_{i}+\varepsilon_{i}$

\section{Results and Discussion}

The results and discussion of the estimated probit model are presented in this section. The results are presented in a tabular form and discussion of the regression estimates is first preceded by a presentation of the summary statistics of the major variables used for the empirical estimation as shown in Table 1 . Table 1 shows the descriptive statistics of the variables used for the analysis. The dependent variable Own_MI is captured as dummy, which takes on a value of one (1) if a respondent has taken decision to own microinsurance policy as guarantee for business risk management and zero (0) otherwise. Age is a continuous variable measured as number of years of the respondent; the mean age is given as 38 years. The variable depend is captured as a continuous variable and it is used to measure the number of dependent children below 18 years and number of dependent adults above 60 years with a mean number of 3.717 or approximately four (4) dependents. Also, the variable Fin_Lit denotes the respondent's level of financial literacy, which is a composite index measure of the respondent's level of financial knowledge. 
Table 1: Summary Statistics of Variable used for the Probit Model

\begin{tabular}{lllll}
\hline Variables & Description & Obs. & Mean & Std. Dev. \\
\hline Own-MI & Micro-insurance Ownership & & & \\
Age & Number of years & 612 & 38.058 & 11.559 \\
Depend & Number of Dependents & 612 & 3.717 & 2.602 \\
Fin_Lit & Financial literacy index & 612 & 9.542 & 3.500 \\
Income & Amount of daily income & 588 & 191.095 & 166.471 \\
Years_Biz & No. of years in business & 612 & 10.982 & 9.504 \\
Market levy & Amount of market levy & 612 & 14.197 & 7.740 \\
Numbacty & No. of economic activities & 612 & 2.054 & 1.123 \\
\hline
\end{tabular}

Source: Field Survey data, (2014)

Also, income is average amount of daily business income measured in Ghana cedis. The mean daily income is given as GH\$191.095. The number of years the respondent has engaged in commercial market business is denoted by Years_Biz with a mean number of years in business given as 10.982 or approximately 11 years. The variable Market Levy measures the amount in Ghana cedis paid per month as levy for occupying a market space by the respondent. The mean value of Market Levy is GH\$14.00. The number of income generating business activities that the respondent owns and actively engages in as at the time of this study is also captured as Numbacty with a mean number of two (2) income generating activities. Table 2 presents the percentage distributions of the categorical variables used in the Probit model across the different categories of the correlates of the dependent variable.

Table 2: Distribution of Respondents across Different Categories of the Correlates of Micro-Insurance Ownership Decision

\begin{tabular}{|c|c|c|c|}
\hline Variables & Description & Frequency & Percentage \\
\hline \multirow[t]{3}{*}{ Sex } & Sex of the respondent: & & \\
\hline & Female Respondents & 372 & 60.78 \\
\hline & Male respondents & 240 & 39.21 \\
\hline \multirow[t]{5}{*}{ Mari_Stat } & $\begin{array}{l}\text { Current Marital Status of } \\
\text { respondents: }\end{array}$ & & \\
\hline & Single & 194 & 31.6 \\
\hline & Married & 334 & 54.5 \\
\hline & Divorced & 57 & 9.3 \\
\hline & Widowed & 27 & 4.4 \\
\hline \multirow[t]{3}{*}{ Credit_access } & Access to credit facility: & & \\
\hline & $\begin{array}{l}\text { Respondents who have } \\
\text { accessed credit facility }\end{array}$ & 267 & 43.62 \\
\hline & $\begin{array}{l}\text { Respondents who have not } \\
\text { accessed credit facility }\end{array}$ & 345 & 56.37 \\
\hline \multirow[t]{3}{*}{$\mathrm{HhH}$} & $\begin{array}{ll}\text { Household } & \text { Headship } \\
\text { Status: }\end{array}$ & & \\
\hline & $\begin{array}{l}\text { Respondents who are } \\
\text { Heads of a household }\end{array}$ & 235 & 38.39 \\
\hline & $\begin{array}{l}\text { Respondents who are not } \\
\text { heads of a household }\end{array}$ & 377 & 61.60 \\
\hline \multirow[t]{3}{*}{ Trust } & Trust in Micro-insurance: & & \\
\hline & $\begin{array}{l}\text { Respondents with trust } \\
\text { micro-insurance }\end{array}$ & 362 & 59.34 \\
\hline & $\begin{array}{l}\text { Respondents who do not } \\
\text { trust in micro-insurance }\end{array}$ & 248 & 40.65 \\
\hline
\end{tabular}

Source: Field survey data, (2014)

Also, Sex and marital status (Mari_stat) are sets of categorical variables, which capture individual demographic characteristics of the respondent. Again, the variable Credit_access is a categorical variable which takes a value one (1) if the respondent has accessed credit facility from a microfinance institution or 
bank within the past two years and zero (0) otherwise. The variable denoted by Trust is a categorical variable, which measures the trust and confidence that the respondent has in micro-insurance policy as a guarantee for business risk management. Also, the variable denoted by $\mathbf{H h H}$ measures household headship status. It is a categorical variable, which takes a value one (1) if the respondent is the head of his or her household and zero (0) otherwise. Table 3 presents results of the regression estimates from the probit model. Also, the discussion of the econometric analysis is followed immediately after the presentation of the results.

Table 3: Probit Results for Determinants of Micro-Insurance Ownership Decision

\begin{tabular}{|c|c|c|c|}
\hline Variables & Coefficient & Marginal Effect & P-value \\
\hline Sex & $\begin{array}{l}-0.228 \\
(-1.64)\end{array}$ & -0.064 & 0.102 \\
\hline Age & $\begin{array}{l}0.002 \\
(0.32)\end{array}$ & 0.007 & 0.747 \\
\hline Marital Status: Base $=$ Widowed & - & - & - \\
\hline Single & $\begin{array}{l}0.190^{* * *} \\
(3.27)\end{array}$ & 0.294 & 0.001 \\
\hline Married & $\begin{array}{l}0.728^{* *} \\
(2.30)\end{array}$ & 0.154 & 0.022 \\
\hline Divorced & $\begin{array}{l}0.030 \\
(0.08)\end{array}$ & 0.004 & 0.935 \\
\hline Depend & $\begin{array}{l}0.031 \\
(1.32)\end{array}$ & 0.008 & 0.188 \\
\hline Fin_Lit & $\begin{array}{l}0.055^{* * *} \\
(2.86)\end{array}$ & 0.015 & 0.004 \\
\hline Income & $\begin{array}{l}0.125^{*} \\
(1.82)\end{array}$ & 0.035 & 0.069 \\
\hline Years_Biz & $\begin{array}{l}0.012 \\
(1.52)\end{array}$ & 0.003 & 0.129 \\
\hline Market Levy & $\begin{array}{l}-0.022^{* * *} \\
(2.98)\end{array}$ & 0.006 & 0.003 \\
\hline Credit_access & $\begin{array}{l}0.427^{* * *} \\
(3.36)\end{array}$ & 0.120 & 0.001 \\
\hline Trust & $\begin{array}{l}-0.587^{* * *} \\
(4.47)\end{array}$ & -0.165 & 0.000 \\
\hline $\mathrm{HhH}$ & $\begin{array}{l}0.273^{*} \\
(1.82)\end{array}$ & 0.077 & 0.068 \\
\hline Numbacty & $\begin{array}{l}0.116 \\
(0.76)\end{array}$ & 0.032 & 0.449 \\
\hline Constant & $\begin{array}{l}-3.915^{* * *} \\
(-6.32) \\
\end{array}$ & - & 0.000 \\
\hline Number of Observations & 586 & & \\
\hline PseudoR ${ }^{2}$ & 0.1448 & & \\
\hline Goodness-of-fit test (P-value) & 0.2416 & & \\
\hline $\begin{array}{l}\text { Linktest_hatsq (P-value) } \\
\text { t-statistics in parentheses }\end{array}$ & 0.545 & & \\
\hline
\end{tabular}

The focus of the study is to examine empirically, determinants of Micro-insurance ownership decision. The probit estimation results presented in Table 3 show that single and married categories of marital status significantly increase the probability of micro-insurance ownership decision. The possible explanation for this finding could be that, single individuals are more concerned about the future prospects of their businesses partly due to the fact that, singles who are planning to build families and expand their business to a sustainable livelihood are more likely to worry about the future security of their businesses and hence, more inclined to take micro-insurance purchase decision compared to their counterparts who are widowed, 
who have been used as the reference category. This revelation compares keenly with a related study into effect of social and demographic factors on insurance demand in Croatia by Curak, Dzaja, \& Pepur(2013); who revealed that significant proportion of unmarried respondents were more inclined to insure against risk. Similarly, there is higher probability to own micro-insurance by married people because of possibility on the part of married couples, all things being equal, to pool resources together when it comes to insurance purchase decision so that they can insure their livelihoods for the family in case of unexpected livelihood risk. This finding compares favorably with related study by Akotey, Osei, \& Gemegah(2011) who found positive relationship between marital status and micro-insurance demand. In fact, a number of married respondents contacted during the study believed purchasing insurance could be effective and sustainable if the couple had enough financial resources as a pool, given other equally important economic demands in the face of limited resources.

Also, the regression results show that financial literacy (Fin_Lit) has a positive and statistically significant relationship with micro-insurance ownership decision. The coefficient of Fin_Lit given as 0.055 is statistically significant at $1 \%$. This, therefore, suggests that an improvement in individual's financial knowledge and/or financial literacy increases the probability that an individual will own micro-insurance, all other factors held constant. Indeed, the connection between consumer financial knowledge and control over financial matters is viewed as major determinant of conscious participation in the financial market and utilization of wide range of financial services (Moore, 2003). Also, financial literacy or financial knowledge enhances the individual's capacity in terms of how well he or she can understand and utilize personal finance related information. The marginal effect of (0.015) suggests that an improvement in the informal commercial market business operator's financial knowledge and/or literacy increases the probability of micro-insurance ownership decision by 0.015 all things being equal. This finding is strongly underpinned by theory. For instance, it is maintained that, the reluctance of commercial financial intermediaries to extend microfinance services to the poor lies in the inability of the target group to go through application formalities due to financial illiteracy(Khan, 2008). This stands to suggest that informal commercial market business operator's knowledge about the function of the financial market and financial products have positive impact on portfolio allocation and hence, micro-insurance ownership decision. The results of this study confirm related empirical study by Guatam \& Kumar(2012)and Boateng \& Awunyor-Vitor(2013), which indicate that, for efficient insurance patronage, financial service education and awareness creation about importance of microinsurance have favorable implications for successful micro-insurance service delivery.

The study has revealed that an increase in informal commercial market business operator's income increases the probability that a commercial market business operator will decide to own micro-insurance scheme all other things being equal. The marginal effect of 0.035 indicates that an increase in daily income by GH $\$ 1.00$ on the average, increases the probability that a commercial market business operator will decide to own micro-insurance by 0.035 . This positive relationship between income and decision to own micro-insurance confirms similar empirical study by Browne \& Hoyt,(2000), which confirms that individuals with more financial resource base are more likely to take advantage of insurance scheme to smooth consumption. This assertion is also reiterated in a related study by Gautam \& Kumar,(2012), which have empirically confirmed the fact that, income is significant determinant of insurance service patronage because an increase in come provides opportunity for individual decision makers to make effective demand decision. Thus, the very fact that low-income households are also concerned about unexpected risk; but their financial situations generally exclude them from purchasing micro-insurance has major implication for income sustainability policy for the poor and the vulnerable. On the relationship between micro-insurance ownership decision and market levy, the study shows that payment of market levy decreases the probability that a commercial market business operator will decide to own micro-insurance. The marginal effect indicates that an increase in the amount paid as market levy to occupy a market space decreases the probability that a commercial market business operator will decide to own micro-insurance by 0.006 all things being equal. This finding supports similar empirical finding reiterated by Baah-Ennumh \& Adom-Asamoah (2012) in reference to operations of informal commercial market women in Ghana, who identified the importance of revenue collection through market levies as major sources of income to the local authorities. However, such financial commitments from the limited resources of the market operators bring financial burden on the part of the market participants to bear. This burdensome situation could preclude most market business operators from making decision to patronize micro-insurance scheme. 
Again, the study reveals that credit access (credit_access) has positive association with micro-insurance ownership decision. The 0.120 marginal effect for credit access means access to credit facility increases the probability that a commercial market business operator will decide to own micro-insurance by 0.120 all other things held fixed. This is an indication that commercial market business operators who are able to access credit from either Microfinance Institutions (MFIs) or banks are able to rely on additional income resources outside the business income to finance micro-insurance purchase. Credit access also serves as the basis for channeling more financial resources into the informal market business activities therefore, enabling the commercial market business operator to generate extra income to finance micro-insurance purchase decision. The positive relationship found between credit access and micro-insurance ownership decision is emphasized in an earlier related study by Morelli et al. (2010) who maintain that credit access through microfinance institutions or a bank helps poor households to finance payment of any micro-insurance premium charge; this is expected to make an individual more inclined to patronize micro-insurance scheme when offered the opportunity.

Further, the study shows that Trust is negatively associated with micro-insurance ownership decision. This suggests that the probability that a commercial market business operator will own micro-insurance decreases with trust in micro-insurance scheme. Thus, the marginal effect of -0.165 means the probability that a commercial market operator will decide to own micro-insurance scheme decreases by 0.165 with trust, all things being equal. This finding is possible especially in the developing world, particularly in Ghana, due to negative perception and attitude towards insurance. The perception possibly emanates from the perceived uncertainties about insurance contract. This concern emerged from the respondents during the data collection exercise. The respondents mentioned news and confirmed experiences of relatives and friends about delay in claim settlement and poor contract terms as reasons for their disinclination to own insurance. This suggests that micro-insurance providers must build reputation via removal of rigidities and other bureaucratic tendencies that dent the reputation of insurance providers. This finding is well reiterated in Yusuf, Gbadamosi, \&Hamadu(2009) which confirmed that, most often, the negative perception and attitudes formed by the insuring public about insurance in general; are clear reflection of low patronage of microinsurance scheme.

Again, from the results of this study, household headship status (HhH) associates positively with microinsurance ownership decision. The marginal effect of 0.077 indicates that being the head of a household increases the probability that a commercial market business operator will own micro-insurance by 0.077 , holding all other factors constant. This finding is possible in the sense that household heads are very often more concerned about the current and future welfare of the household. Thus, for purposes of smooth consumption in the event of unexpected risk, household heads are most often highly probable of making insurance decision. This finding is in line with similar finding by Bendig et al. (2011) who assert that, most household heads are the primary caregivers and breadwinners who are concerned about future wellbeing of the household members thus, the head of the household views micro-insurance as a hedge against loss of livelihood and income. Therefore, the income earning household head has high probability, thus, more inclined to take insurance purchase decision against future risk.

\section{Conclusion and Recommendations}

The study investigated determinants of micro-insurance ownership decision in Ghana. The results of probit regression estimates suggest that financial literacy, income credit access and household headship status increase the probability of micro-insurance ownership decision. However, market levy and trust decrease the probability of micro-insurance ownership decision. This implies that increasing financial knowledge and improving income generation and credit access are crucial in ensuring patronage of micro-insurance scheme among informal commercial businesses in Ghana. It is recommended that micro-insurances service providers should invest in financial literacy education to increase patronage of micro-insurance. It is also recommended that efforts of government should focus on improving access to credit facilities and income generation prospects in order to increase micro-insurance patronage among informal business operators in Ghana. 


\section{References}

Ackah, C., \& Adobea, O. (2012). Assessing the knowledge and attitude towards insurance in Ghana. Retrieved from http://www.utwente.nl/.../2012/microinsurance.

Adjei, J., Arun, T., \& Hossain, F. (2009). Asset building and poverty reduction in Ghana: The case of microfinance. Savings and Development, 33(3), 265-291.

Akotey, O., \& Adjasi, C. (2014). The impact of Micro-insurance on household asset accumulation in Ghana: An asset index approach. The Geneva Papers on Risk and Insurance-Issues and Practice, 39(2), 304-321.

Akotey, O., Osei, K., \& Gemegah, A. (2011). The demand for micro-insurance in Ghana. The Journal of Risk Finance, 12(3), 182-194.

Akter, S. (2012). The role of microinsurance as a safety net against environmental risk in Bangladesh. Journal of Environment and Development, 21(2), 263- 280.

Annim, S., \& Alnaa, S. (2013). Access to microfinance by rural women: Implications for poverty reduction in Rural Households in Ghana. Research in Applied Economics, 5(2), 19-41.

Arun, T., \& Bendig, M. (2010). Risk management among the poor: The case of microfinancial services. University of Central Lancashire, United Kingdom: Brooks World Poverty Institute. (IZA DP No. 5174).

Baah-Ennumh, T., \& Adom-Asamoah, G. (2012). The role of market women in the informal market economy in Kumasi. Journal of Science and Technology, 32(2), 56-67.

Bateman. (2010). Why doesn't microfinance work? The destructive rise of Local Neoliberalism. London: Zed Books.

Bendig, M., \& Giesbert, L. S. (2011). Microfinancial services and risk management: Evidences from Sri Lanka. Journal of Economic Development, 36(4), 97-126.

Boateng, D., \& Awunyor-Vitor, D. (2013). Health insurance in Ghana: Evaluation of policy holders' perceptions and factors influencing policy renewal in the Volta Region. International Journal for Equity in Health, 12(50), 1-10.

Browne, M., \& Hoyt, R. (2000). The Demand for flood insurance: Empirical evidence. Journal of Risk and Uncertainty, 20(3), 291-306.

Chowdbury, T., Rahman, M., \& Afza, S. (2007). Perceptions of the customers towards insurance companies in Bangladesh: A study based on the Survqual Model. BRAC University Journal, 4(2), 55-66.

Cole, S., Sampson, T., \& Zia, B. (2009). Financial Literacy, financial decisions and the demand for financial services: Evidence from India and Indonesia (HBS Working Paper No. 09-119). Harvard, United States of America: World Bank Finance Seminar on Financial Literacy and Consumer Protection.

Crayen, D., Hainz, C., \& Stoh de Martinez, C. (2013). Remittances, banking status and the usage of insurance schemes. The Journal of Development Studies, 49(6), 861-875.

Curak, M., Dzaja, I., \& Pepur, S. (2013). The effect of social and demographic factors on Life insurance demand in Croatia. International Journal of Business and Social Science, 4(9), 65-72.

Dulleck, U., \& Kerschbamer, R. (2006). On doctors, mechanics, and computer specialits: The economics of credence goods. Journal of Economic Literature, 44, 5-42.

Fafchamps, M. (2010). Vulnerability, risk management and agricultural development. The African Journal of Agricultural and Resource Economics, 243- 260.

Fletschner, D., \& Kenney, L. (2011). Rural women's access to financial services: Credit, savings and insurance. World Development, 37(3), 618-631.

Fofie, G. (2016). What influence customer patronage of insurance policies: An empirical assessment of socioeconomic and demographic determinants of insurance patronage in Ghana. International Review of Management and Marketing, 6(1), 81-88.

Gaurav, S., Cole, S., \& Tobacman, J. (2011). Marketing complex financial products in emerging markets: Evidence from rainfall insurance in India. Journal of Marketing Research, 48, 150-162.

Gautam, V., \& Kumar, M. (2012). A Study on attitudes of Indian consumers towards insurance services. Management Research and Practice, 4(1), 51-62.

Guha-Khasnobis \& Ahuja. (2004). Extending formal insurance to the informal economy workers in India. Paper presented at EIGD and UNU-WIDER conference. Helsinki.

Gurley \& Shaw. (1967). Financial structure and economic development. Economic Development and Cultural Change,15(3), 257-268.

Hassan, M., Sanchez, B., \& Yu, S. (2011). Financial Development and Economic Growth. The Quarterly Review of Economics and Finance, 51, 88-104. 
Hoefer, R., \& Midgley, J. (2012). Poverty, incomes and social protection: International Policy Perspectives. Journal of Policy Practice 11, 1-7.

Holzmann, Sherbune \& Tesliuc. (2003). Social risk management: The World Bank's approach to social protection in a globalizing world. Retrieved from http://www.worldbank.org/sp

IFAD. (2004). Investing in Microfinance. Retrieved from Investing in Microfinance: http://www.ifad.org/events/

Ito, S., \& Kono, H. (2010). Why is the take-up of micro-insurance so low? Evidence from a health insurance scheme in India. The Developing Economies, 48(1), 74-101.

Janzen \& Carter. (2013). The Impact of Microinsurance on Consumption Smoothing and Asset Protection: Evidence from a Drought in Kenya. Paper prepared for Agricultural \& Applied Economics Association's Joint Annual Meeting in Washington DC, Au. Washington DC.

Khan, A. A. (2008). Islamic microfinance: Theory, policy and practice. Retrieved from http://www.islamicrelief.com

Kishor. (2013). Micro Insurance in India: Protecting the Poor. Journal of Business Management and Social Sciences Research, 2(3), 39-44.

Lusardi, A., \& Mitchell, O. (2007). Financial literacy and retirement preparedness: Evidence and implications for financial education. Business Economics, 42(1). Business Economics, 42(1), 35-44.

Mckinnon \& Goldsmith. (1973). Money and capital in economic development. Washington DC: Brookings Institution Press.

Moore, D. (2003). Survey of financial literacy in Washington State: Knowledge, behaviour, attitude and experiences. Washington State, United States of America: Washington State Department of Financial Instructions. (SESRC Technical Report No. 03-09).

Morelli, E., Onnis, G. A., Ammann, W. J., \& Sutter, C. (2010). Microinsurance. An innovative tool for risk and disaster management. Global risk forum. Davos.

Mukhtar, S. (2013). Insuring the insurable for poverty alleviation in Nigeria: What Micro- insurance can do? Mediterranean Journal of Social Sciences, 4(2), 375-380.

National Insurance Commission. (2010). Annual Report 2010. Accra: National Insurance Commission.

Negi, D., \& Singh, P. (2012). Demographic analysis of factors Influencing purchase of life insurance product in India. European Journal of Business and Management, 4(7), 169-180.

Parvathi, G. (2012). Micro-insurance in India. International Journal of Research in Management, Economics and Commerce, 2(11), 268-273.

Stango, V., \& Zinman, J. (2006). Fuzzy Math and Red Ink: Payment/Interest Bias, Intertemporal Choice and wealth accumulation. Hanover: NH: Dartmouth College.

Tabea, G. (2010). Does micro-insurance improve social inclusion? Overview over empirical evidence. Retrieved from http://www.fflch.usp.br/centrodametropole//upload.pdf

Veron, R., \& Majumdar, A. (2011). Micro-insurance through Corporate-NGO Partnerships in West Bengal: Opportunities and constraints. Development in Practice 21(1), 122-129.

World Bank. (2009). The Case for financial literacy in developing countries: Promoting access to finance by empowering consumers. Washington DC. Retrieved from http://www.mfw4a.org

Yusuf, T. O., Gbadamosi, A., \& Hamadu, D. (2009). Attitudes of Nigerians towards insurance services: An Empirical Study. African Journal of Accounting, Economics, Finance \& Banking Research (4), 34-46. 